\title{
ОКРЕМІ ПИТАННЯ ДЕКЛАРУВАННЯ ЯК ОСНОВНОГО СКЛАДНИКА МИТНОГО ОФОРМЛЕННЯ
}

Лicozop Ю. 5.

Однією з умов пропуску товарів і транспортних засобів комерційного призначення через митний кордон України є їх декларування. На жаль, натепер питання правового регулювання інституту митного оформлення і його основного складника - митного декларування залишається не досить вивченим. Отже, стаття присвячена декларуванню як встановленому чинним законодавством порядку переміщення через митний кордон вантажів під контролем митних органів. У статті аналізуються основні етапи митного оформлення. Розглядаються види декларування, їх характерні риси. Констатується наявна проблемність окремих положень, присутніх у Митному кодексі та інших нормативно-правових актах. Наголошено на важливості технологічного вдосконалення процедури митного декларування.

Ключові слова: декларування, митна декларація, митний орган, митне оформлення, кодекс, митна справа.

Одним из условий пропуска товаров и транспортных средств коммерческого назначения через таможенную границу Украины является их декларирование. $K$ сожалению, на сегодняшний день вопросы правового регулирования института таможенного оформления и его основной составляющей - таможенного декларирования остаются недостаточно изученными. Итак, статья посвящена декларированию в установленном действующим законодательством порядке перемещения через таможенную границу грузов под контролем таможенного органа. В статье анализируются основные этапы таможенного оформления. Рассматриваются виды декларирования, их характерные черты. Констатируются проблемы отдельных положений, присутствующих в Таможенном кодексе и других нормативно-правовых актах. Подчёркнута важность технологического совершенствования процедуры таможенного декларирования.

Ключевые слова: декларирование, таможенная декларация, таможенный орган, таможенное оформление, кодекс, таможенное дело.

The article deals with the process of declaration as legally established procedure for movement of goods across the customs border under the supervision of the customs authorities. This article analyzes the main stages of customs clearance. We consider the types of declaring and their characteristics. The article deals with the problems of certain provisions present in the Customs Code and other legal acts. Emphasized the importance of technological improvement of customs declaration. The article analyzes the legal nature of the customs declaration. The relation with the institute of customs clearance.

The article also deals with the legal regulation of the procedure of administrative services by the customs authorities of Ukraine on the principle of "single window". The author analyzes the results of administrative services on the principle of "single window", identifies gaps and makes suggestions to improve the organization.

Have stated and proved the author's approach to the establishment of the internal structure of the customs clearance

Лісогор Ю. Б., 2019 and the ratio of its components, as well as the role and importance of the preliminary documentary control the customs and its relationship with the customs control over the movement of goods across the customs border of Ukraine. The role of new technologies in the implementation of customs control and customs clearance. Special attention is paid to the analysis and management of risk when moving goods across borders.

Attention is paid to the fact that legal documents should indicate, who and under what conditions should adopt and implement a "single window" and methods of protection of rights of legal relations arising in the declaration.

Developed proposals and recommendations for the development and improvement of customs clearance in the mode of "single window".

Key words: declaration, customs declaration, customs agency, customs clearance, Code, customs, single window, administrative services.

Постановка проблеми. Набуття Україною державного суверенітету зумовило потребу в приведенні правових засад державної митної справи у відповідність до загальновизнаних міжнародних норм та правил. Результатом 26-річного законотворчого процесу в цьому напрямі стало створення для суб'єктів господарювання сприятливих умов щодо вільного здійснення зовнішньоекономічної діяльності.

Однією з умов пропуску товарів і транспортних засобів комерційного призначення через митний кордон України $\epsilon$ їх декларування. На жаль, натепер питання правового регулювання інституту митного оформлення і його основного складника - митного декларування залишається не досить вивченим. Відсутній структурний науково-практичний аналіз процесу митного декларування як правового явища. Поза рамками системного дослідження перебувають питання контакту і взаємодії адміністративних правовідносин у сфері митного декларування з правовідносинами, що регулюються нормами цивільного, фінансового, інформаційного та інших галузей права.

Одним із проблемних питань $\epsilon$ питання правового регулювання процедури надання контролюючими органами адміністративних послуг у режимі «єдине вікно» та діяльності митних органів під час здійснення митних формальностей, пов'язаних з митним оформленням і безпосередньо митним декларуванням.

Процес структурного реформування митної системи супроводжується проблемами, пов'язаними в тому числі із неможливістю вирішення повною мірою питань взаємодії органів доходів та зборів з іншими контролюючими службами. Насамперед це стосується питань взаємодії з представниками органів виконавчої влади, які здійснюють санітарно-епідеміологічний, ветеринарний, фітосанітарний, радіологічний, екологічний та інші види контролю.

Стан опрацювання. Аналізуючи стан наукового дослідження розглянутої тематики, можна зробити 
висновок, що науковому аналізу піддавалися більшою мірою загальні аспекти, пов'язані з процесом митного декларування.

Окремі питання правового регулювання, що характеризують природу адміністративно-процесуальних правовідносин у галузі митного декларування, розглянуті в наукових працях таких учених, як: С.С. Алексєєв, Ю.П. Битяк, І.Г. Бережнюк, К.Г. Борисов, І.В. Бойко, А.Д. Войцещук, Р.В. Дзугаєв, Є.В. Додін, Л.М. Ентін, Д.О. Єршов, С.С. Жамкочьян, А.Т. Комзюк, Д.В. Приймаченко, К.К. Сандровський, П.В. Пашко та інші.

Загальним науково-теоретичним підґрунтям для досліджуваної проблеми послужили роботи вітчизняних і зарубіжних учених у галузях теорії права, теорії державного управління, адміністративного права, митного права: В.Б. Авер'янова, О.Ф. Андрійко, А.І. Берлача, Ю.П. Битяка, Б.М. Габричидзе, В.М. Гаращука, Т.О. Гуржія, Ю.М. Дьоміна, В.П. Колісника, В.К. Колпакова, Т.О. Коломоєць, А.В. Кольбенка, О.В. Кузьменко, М.П. Кучерявенка, А.В. Мазура, В.Я. Настюка, В.І. Олефіра, В.В. Прокопенка, М.М. Тищенка, Ю.С. Шемшученка, П.М. Шеремети, М.Г. Шульги та ін.

Рівень дослідження теми не дає можливість вирішити всі проблемні питання правового регулювання інституту митного оформлення i його основної складника - митного декларування.

Особливо проблематика цього питання помітна в аспекті впровадження практики «єдиного вікна» та електронного декларування загалом. Це, своєю чергою, зумовлює необхідність подальшого наукового опрацювання питань адміністративно-правових правовідносин, що виникають у процесі декларування товарів та транспортних засобів комерційного призначення.

Мета статті. Метою цієї статті $€$ проведення дослідження окремих складників митного оформлення, а саме декларування в розрізі проблематики реалізації інноваційного принципу «єдиного вікна» під час здійснення митного контролю.

Результати. Митне декларування необхідно розглядати як основну процедуру митного оформлення, що в сукупності з іншими елементами системи відповідних митних процедур утворює інститут митного оформлення. Як відокремлена система правових норм він утворює окрему ланку складного митного провадження в системі адміністративного процесу. Митному оформленню, як окремому інституту права, притаманні свої принципи, що діють у межах однорідних суспільних відносин, які своєю чергою регулюється однорідними правовими нормами.

Предметомправовогорегулюваннявінститутімитного оформлення виступають соціальні відносини, що виникають у процесі здійснення митного оформлення товарів і транспортних засобів комерційного призначення.

Митне декларування виконує декілька основних функцій:

- забезпечення Державної фіскальної служби України необхідними відомостями про товари і транспортні засоби;

- підтвердження декларантом правомірності вчинених дій щодо товарів і транспортних засобів, які переміщуються;

- контролю за дотриманням суб'єктами зовнішньоекономічної діяльності та фізичними особами законодавства України.
Процедура та вимоги до декларування визначені статтями 257-269 Митного кодексу України [1].

Колектив авторів навчального посібника «Митне право України» за загальною редакцією проф. В.В. Ченцова зазначає, що законодавцем встановлено письмову, усну та конклюдентну (шляхом вчинення дій) форми митного декларування [2, с. 164]. При цьому вченими та практиками в галузі митного права усна і конклюдентна форми декларування розглядаються як самостійні. До речі, у нормативних документах це питання досить не відображено. У зв'язку з чим пропонується внести зміни до ст. 257 МК України і розглядати усну та конклюдентну форми митного декларування нарівні з електронною формою декларування як окремі за формою процедури.

Окрім цього, М.М. Каленський і П.В. Пашко, досліджуючи питання митного декларування, визначають, що основною формою декларування $є$ письмова форма, при цьому одним із підвидів письмової форми декларування $\epsilon$ електронна форма, за якої використовуються документи у електронному вигляді. У разі застосування письмової форми декларування можуть використовуватися як електронні документи, так і документи на паперовому носії, що мають однакову юридичну силу [3, с. 254].

Необхідно зауважити, що під час митного декларування суб'єкти митних правовідносин мають бути наділені особливою правосуб'єктністю. 3 одного боку, це безпосередньо суб'єкти ЗЕД, особи, що беруть участь у процесі декларування, такі як: митні брокери, агенти з митного оформлення, митні перевізники, експедитори, власники митних ліцензійних складів та складів тимчасового зберігання, інші особи, що здійснюють свою діяльність на основі цивільно-правових угод із суб'єктами ЗЕД. 3 іншого боку, це - органи доходів і зборів та їхні посадові особи, спеціально уповноважені в питаннях митної справи. Ця обставина відображає диспозитивний метод правового регулювання інституту митного оформлення і безпосередньо процедуру митного декларування.

Варто зауважити, що у чинній редакції Митного кодексу відсутнє поняття особи митного експедитора. У зв'язку з чим пропонується внести зміни до статті 191 МК України: нарівні із митним перевізником прописати особу митного експедитора із визначенням їі правового статусу як повноправного суб'єкта митних правовідносин.

Аналізуючи правову природу декларування, $\epsilon$ сенс розглядати митне декларування не тільки як окрему митну процедуру, але і як адміністративне неюрисдикційне дозвільне провадження, здійснюване митним органом у спосіб і в порядку, визначені законодавством.

Електронне декларування здійснюється з використанням електронної митної декларації. Застосування цієї інноваційної технології набуває актуальності в контексті європейської інтеграції України, адже багато країн Європи вже впровадили таку процедуру у сфері зовнішньоекономічної діяльності.

Варто зазначити, що повний перехід до електронного декларування позитивно вплине на роботу підприємств, оскільки у них з'явиться можливість декларувати товари шляхом подання документів виключно в електронному вигляді, що своєю чергою дасть змогу не тільки заощаджувати час на здійснення митних фор- 
мальностей, але й сприятиме підвищенню ефективності проведення митних процедур. Також така форма декларування сприяє зменшенню корупції, позаяк вона передбачає безконтактний метод роботи.

Застосування електронного цифрового підпису в електронних документах здійснюється із використанням послуг акредитованого центру сертифікації ключів відповідно до Закону України «Про електронний цифровий підпис» [4, с. 5].

За безконтактним методом декларант подає митну декларацію із заявленим митним режимом та документи, необхідні для здійснення митного оформлення, шляхом використання інформаційно-телекомунікаційних систем та сертифікованого програмного забезпечення. Декларація подається безпосередньо в підрозділ органу доходів і зборів, в якому проводиться митне оформлення. Процес обробки інформації та опрацювання поданих документів здійснюється за відсутності декларанта. Винятки становить необхідність проведення митного догляду у разі спрацювання критеріїв безпеки АСАУР (автоматизованої системи аналізу та управління ризиками), за рішенням посадової особи митного органу.

Як зазначає B.I. Царенко в своїй науковій статті «Митні процедури: ознаки та поняття», згідно з правилом 3.16, стандартним правилом розд. 3 Загального додатка до «Міжнародної конвенції про спрощення і гармонізацію митних процедур», на підтвердження декларації на товари митна служба вимагає тільки ті документи, які необхідні для проведення контролю за такою операцією і забезпечення виконання всіх вимог щодо застосування митного законодавства [5].

Рішення про запровадження «єдиного вікна» було прийнято 25 травня 2016 року Постановою Кабінету Міністрів України № 364 від 25.05.2016 «Деякі питання реалізації принципу «єдиного вікна» під час здійснення митного, санітарно-епідеміологічного, ветеринарно-санітарного, фітосанітарного, екологічного, радіологічного та інших видів державного контролю» [6].

Рівень правового регулювання митного оформлення і зокрема процедури декларування, що здійснюється за цією інноваційною технологією, не повною мірою відповідає вирішенню задачі комплексного реформування вітчизняної митної системи. Питання взаємодії контролюючих органів, від яких залежить проведення митного оформлення, в нормативно-правових документах висвітлене досить декларативно. Така неузгодженість підтверджується практикою здійснення митного оформлення і зокрема процедури митного декларування.

Моменту подання до митного органу декларації передує проведення різноманітних видів контролю із поданням контролюючим органам необхідних документів в електронному вигляді. Це за задумом законодавця має скоротити час митного оформлення і забезпечити «безконтактність» надання адміністративної послуги.

На практиці проведення вищезазначених видів контролю потребує надання необхідних дозвільних документів обов'язково у паперовому вигляді безпосередньо посадовій особі. Завершення певного виду контролю досить часто потребує надання додаткових дозвільних документів або проведення певних додаткових процедур (лабораторних випробувань, реєстрації у відповідних службах тощо). Ці дії функціонально та процедурно не мають безпосереднього відношення до питання митного декларування.
Здійснення процедур контролю потребує термінів, що значно перевищують задекларований нормативними документами час на проведення митного оформлення (митне оформлення завершується протягом 4 робочих годин)(стаття 255 МК України) [1].

Наказом Державної служби України з питань безпечності харчових продуктів та захисту прав споживачів № 517 від 23.12.2016 р. затверджений термін видачі висновку санітарно-епідеміологічної експертизи, що становить 30 робочих днів [7]! Увесь час, поки проводиться процедура розгляду та видачі висновку державної санітарно-епідеміологічної експертизи, імпортовані товари перебувають під митним контролем. Митне оформлення не здійснюється, митні платежі своєчасно не надходять до бюджету, а товари до споживачів. Такий приклад непоодинокий, проблема проходження видів контролю має системний характер.

Наявний стан речей пов'язаний насамперед із невідповідним правовим врегулюванням правозастосовної діяльності окремих суб'єктів, що беруть участь у митному оформленні.

Для вирішення спірних правових питань, які заважають впровадженню програми «електронна митниця» та «єдине вікно» і практично унеможливлюють організацію митного декларування на рівні, що задекларований у нормативно-правових актах ДФС України, на нашу думку, необхідно реалізувати такі моменти:

у результаті нормотворчої діяльності в галузі митної справи необхідно повною мірою реалізовувати лінійно-функціональний принцип організації державного управління. Реалізація цього принципу допоможе забезпечити розвиток міжгалузевих зв'язків між органами митного контролю та іншими контролюючими службами. Це дасть можливість вирішити питання, що мають спільне значення для різноманітних підрозділів, які беруть учать у процесі здійснення митного оформлення. Також буде сприяти досягненню узгодженості в діяльності галузевих систем управління, дасть змогу забезпечити спеціалізацію управлінської діяльності в галузі митної справи;

з метою конкретизації основних завдань органів доходів та зборів пропонується внести зміни до п. 13, ч. 1, ст. 4. МК України та п. 7, ч. 2, ст. 544 МК України, а саме у змісті поняття «заходи нетарифного регулювання» надати чіткий перелік заборон та обмежень щодо переміщення окремих видів товарів через митний кордон України, відносно яких органи доходів та зборів мають здійснювати контролюючі функції.

Висновки. Узагальнюючи розглянутий матеріал, доцільно зауважити, що митне декларування можна розглядати як адміністративне неюрисдикційне дозвільне провадження, здійснюване митним органом. Разом із тим це основна митна процедура, яка спільно з іншими процедурами утворює інститут митного оформлення.

Зважаючи на пріоритетність курсу України на вступ до Європейської спільноти, питання реформування митного законодавства і приведення його до європейських стандартів набуває особливої значущості. Одним із вдалих рішень на цьому шляху $\epsilon$ впровадження в галузі митного оформлення технології «єдине вікно» та «Електронна митниця».

Реформування сфери митно-правових відносин можливе лише за умови впорядкування нормотворчої діяльності органів законодавчої та виконавчої влади, безпо- 


\section{Проблеми становлення правової демократичної держави}

середньо правозастосовної діяльності органів доходів та зборів. Це, своєю чергою, сприятиме розвитку зовнішньоекономічної діяльності, збільшенню товарообігу та підвищенню статусу України як правової держави.

\section{Література}

1. Митний кодекс України : прийн. Верховною Радою України 13.03.2012 № 4495-VI, редакція від 01.01.2015. URL: http://zakon2.rada.gov.ua/laws/show/4495-17/ paran151\#n151.

2. Митне право України : навчальний посібник. / За заг. ред. проф. В.В. Ченцова. Київ, 2007. 283 с.

3. Каленський М.М., Пашко П.В. Коментар до Митного кодексу України. Київ : УДК, 2013, 501 с.

4. Пархоменко В.П., Ігнатьєва О.В. Процеси введення електронного митного декларування в Україні. Вісник Східноукраїнського національного університету імені В. Даля. 2013. № 4 (193). Ч. 2. С. 138-142.
5. Царенко В.І. Митні процедури: ознаки та поняття / B.I. Царенко, В.О. Хома. URL: http://www.pap.in.ua/ 3_2014/40.pdf.

6. Деякі питання реалізації принципу «єдиного вікна» під час здійснення митного, санітарно-епідеміологічного, ветеринарно-санітарного, фітосанітарного, екологічного, радіологічного та інших видів державного контролю : Постанова Кабінету Міністрів України від 25.06.2016 № 364. URL: http://zakon5.rada.gov.ua/laws/ show $/ 364-2016-\%$ D0\%BF.

7. Наказ Державної служби України з питань безпечності харчових продуктів та захисту прав споживачів № 517 від 23.12.2016 p. URL: http://www.consumer.gov.ua/ ContentPages/Normativno_Pravova_Baza/27/.

Лicozop Ю. Б., аспірант кафедри адміністративного, фінансового та інформаційного права Київського національного торгово-економічного університету 